\title{
From Initiative to Movement: The Growth and Evolution of Local Food Networks in Bandung, Indonesia
}

\author{
Angga Dwiartama ${ }^{1}$, Chandra Tresnadi ${ }^{2}$, Alhilal Furqon ${ }^{3} \&$ Mochammad Fikry Pratama $^{1}$ \\ ${ }^{1}$ School of Life Sciences and Technology, Institut Teknologi Bandung, West Java, Indonesia \\ ${ }^{2}$ Faculty of Arts and Design, Institut Teknologi Bandung, West Java, Indonesia \\ ${ }^{3}$ School of Architecture, Planning and Public Policy, Institut Teknologi Bandung, West Java, Indonesia \\ Correspondence: Angga Dwiartama, School of Life Sciences and Technology, Institut Teknologi Bandung, West \\ Java, 40132, Indonesia. Tel: 62-22-251-1575.
}

Received: November 15, 2017

doi:10.20849/ajsss.v2i4.217
Accepted: December 21, 2017 Online Published: December 27, 2017

URL: https://doi.org/10.20849/ajsss.v2i4.217

\begin{abstract}
Within the last three years, the growth of alternative and local food initiatives in Bandung, a medium-sized city in Indonesia, has been extraordinary. Not only has the number grown rapidly, but the types and modes of entities have also evolved from merely initiatives, to collaborative networks and movements, to the extent that this movement in unity may have the capacity to influence the way in which the local and national governments govern the agricultural sector. Through in-depth interviews, participant observation and a series of group discussions, this paper documents the seemingly smooth transition of agri-environmental practices that are engineered by the community sector in Bandung. The research thus leads to a conclusion that we need to look beyond individual actions in seeing social transformation, and through a coordinated collective movement, there is a promising impact on the sustainability of the local food system in Bandung and elsewhere. Practitioners and activists within the local food networks need to take a precaution in safeguarding this rapid interest in the movement.
\end{abstract}

Keywords: local food movement, initiatives, networks, actors, Bandung, Indonesia

\section{Introduction}

We are currently facing the world in which globalization of food and agriculture brings many impacts on both our society and ecology. Many studies have indicated that local food systems are among the solutions to mitigate these impacts (Hinrichs, 2003; Allen et al., 2003). As the awareness of local food grows in many large metropolitan in developed nations, Indonesia is now undergoing a similar growth stage. Grass root movements, social enterprises and communities are tapping to provide healthier and more environmentally friendly food. In reflecting on the growth of local food movements in countries like United States and others in Europe and Australia, this paper thus aims to document the process in Indonesia, a prominent developing country in the growing economies of Southeast Asia.

In many cities all around the world, local food movements grow in many forms. Some of them include farmers' market, community supported agriculture, comunity gardens, vegetable box scheme, permaculture gardens, organic farming, and others (Dwiartama \& Piatti, 2016; Piatti \& Dwiartama, 2013; Carolan, 2012). In cities like Bristol (UK), Cardiff (UK), Rome (Italy), Vancouver (Canada), and Santa Barbara (USA), these local food systems have been able to be identified and characterized, and they also have been an integral part of the city planning (Allen et al., 2003; Hinrich, 2003; Carolan, 2012). This shows the seriousness of the local government to anticipate the global issues related to food and agriculture. In Indonesia, and Bandung in particular, there has not been any documented attempt to achieve this local food system. This is regardless of the huge potential of youth movement and food culture pertaining in the history of the city itself. It is therefore our intention to document this recurring transformation in the city of Bandung, and consequently in Indonesia, and relates this with the growing movements elsewhere. In so doing, this paper uses the argument that a movement grows from individual actions, or initiatives, that link together in strongly-knitted networks within which its members work together to achieve something bigger than their own goals, a movement. As this paper will reveal, Bandung has a lot to say in regard to a positve growth of this local food movement. 


\section{Methodology}

The study was conducted as part of a participatory action research to build and nurture a local food system in Bandung, the third largest city in the island of Java, Indonesia. We aimed to identify the major actors of this food system and understand the relationships that grow and evolve within them. The study was conducted using semi-structured interviews and a participant observation (Reason \& Bradbury, 2008) in which we involved ourselves in gatherings, local food forums, food festivals, and group discussions that aimed to improve the performance of the food system. Some additional information was also extracted from public documents, group's web profiles, reports and other relevant academic and popular publications.

Semi-structured interviews were conducted between April and October 2017 with 50 individuals ranging in age from approximately 25 to 60 years, representing various groups involved in Bandung's local food system. The duration of each interview ranged from approximately 30 to 90 minutes. A number of open ended questions were used to guide the discussion of the state of local food system. During the interviews, we asked the participants to talk freely about their experience in food and related issues, such as poverty, policy, personal and social meanings, initiatives, alternatives, production, distribution and about perceptions, engagement and involvement within the food system.

Participants were identified at the beginning upon their direct involvement within the production end of the food system (e.g. farmers participating in the local Farmers' Market, i.e. Pasar Sehat). Through a snowball sampling technique (Goodman, 1961), the discussion expanded to other groups that were of significance to the local food system (e.g. activists, local food artisans, NGOs, etc.). We then grouped the participants in thematic clusters, in order to rationalize their involvement in the local community, which will be elaborated in the subsequent part of this paper.

We were also involved in the community gathering and farmers' markets in July, August and October 2017. The importance of such forum was for us to be able to see all the actors who expressed interest in the local food system being together and interacting, thus increasing awareness on the food system and reflexivity (see e.g. DuPuis and Goodman, 2005; Goodman et al. 2011; Mount, 2012:109) to assess critical thinking. The forum was also part of our academic and personal engagement in the community, as part of a praxis as highlighted by Wakefield (2007), for which activism is part of our academic life.

\section{Discussion}

\subsection{Bandung's Sense of Uniqueness}

This paper places Bandung as a particularly unique case in regard to local food system. As the capital city of West Java province, the vibrancy of Bandung in the context of a growing social movement is particularly interesting to unravel. Bandung has an area of $167.7 \mathrm{~km}^{2}$ and ranging from 657 to 1,050 meters altitude above sea level, trapped within a giant basin that was once an ancient crater. This means that Bandung is surrounded by volcanic mountainous area. This basin lies within five administrative regions, which are Bandung municipality, Bandung regency, West Bandung regency, Cimahi municipality and Sumedang regency. It is estimated that Bandung has around 3 million residents, with population density of about 15,713 individual per square kilometres.

What is also interesting about Bandung is the youth (within age range of $15-45$ years old) that includes $50 \%$ of the total population, an opportunity for what is known as demographic bonuses. Youth in Bandung has been known for their creativity, both in terms of art and food. Nevertheless, the agricultural sector only contributes to around $0.14 \%$ of total GDP, whereas food provisioning services contributes to about $4.63 \%$. The largest contributor of GDP in the city is the retail sector (Badan Pusat Statistik [BPS], 2016).

Youth culture in Bandung can be seen as one of the factors influencing the growth of local food movement. Starting out through an organization called Bandung Creative City Forum that was initiated by the incumbent Mayor of Bandung, a movement named Gardening Bandung grew as a national-level movement, which became an initiating factor for the growth of other similar grass root movements. We have been involved in the rapid growth of this type of community movement, which was built on the basis of similar interests in providing alternative, healthy food in many of its forms: organic farming, urban hydroponic systems, farmers' market and seed exchange activities. Communication between members is mainly built through social media, but meetings are often held too.

This, as we argue, has acted as the foundation on which a local food system is built. Stepping from this perspective, this paper seeks to identify key actors and types of activities (that we refer to as clusters) that play 
important roles in the growth of Bandung's local food system. The following is our narrative of the existing food initiatives from which the system develops forward.

\subsection{Local Food Productions and the Farmers' Market}

Amidst conventional family farms and large farming entities with an export-orientated production are a handful of farmers that focus on the provisioning of food for a growing demand of Bandung's population. They are the farmers that we consider as local, defined not solely on the basis of their proximity to markets, but also on their commitment in supporting the local food supply. There are more than 10 local farmers that we have been able to identify, with their products ranging from seasonal vegetables, eggs, fish, dairy products and local fruits. A lot of these local farmers have found a hub that is able to connect them with the consumers, as well as among themselves, in the Pasar Sehat (lit. Healthy Market; similar to farmers' market elsewhere).

An initial seed for this type of market was planted in 2014 by a group of young graduates that started their social business in linking farmers with consumers. Through their farmers' market concept, they involved one local farmer to sell his produces and herbs in a small corner every Sunday in a weekly public event called Car Free Day. There, prospective consumers were expected to interact with the farmers, asked about how the produces were grown, how healthy they were, etc. The project eventually stopped after a year of consistent effort, only to find that consumers were not ready for this kind of initiative yet. However, the idea spreads, and so a few food initiatives (farmers and local artisans) agreed to enliven this concept by making Pasar Sehat, held in public places such as schools once a month or less. It has become a new movement in itself, with participants reaching up to 60 tenants. Similar markets began to follow, to name a few the Green Market, Small Market, Keuken Food Festival, to even a city council-driven Bandung Agri-Market, in response to a growing community interest to this type of alternative market.

To be a tenant in Pasar Sehat, a person needs to comply with four requirements: being a local producer within the Bandung region, selling only food products, must be the same person who has created the product he/she sells, and must make sure that the product sold is healthy and safe. These requirements thus highlight the way in which Pasar Sehat defines local food production in its spatial (embedded within the geographical region) and system (embedded within a particular local activity) contexts (Kjeldsen \& Alroe, 2006). As often discussed in the context of local food (Hinrichs, 2000; Milestad et al., 2010), farmers' market is an epitome of local food movements. However, local food production does not address the extent to which the producers source the raw materials for their production. This fact thus rejects the conception of local within its natural context; that you can produce local bread or cheese with your grains or milk obtained from elsewhere.

\subsection{Food Processing: How Is It Local?}

Based on this conception of local, it is interesting then to include various food processors within Bandung city limits as one of the actors of the local food system. We define food processors as those actors that process agricultural products into goods for the market. Even though restaurants might also be included in this category because of a further activity of processing the food, we made a distinction on the basis of the consumer involvement, highlighting how the food product sold by the food processor needs to be further handled by the consumer for consumption purpose. Included in this cluster of activities are, among others, bakeries, dairy processors, snack makers and kombucha breweries. We have found at least 30 food processors that differ in characteristics and scale - from small-scale artisans to food processing factories. Interestingly, their attachment to the spatiality in which they operate defines them as local.

One aspect of locality comes from the history of Bandung itself, which is entangled with the history of locally bounded culinary products. Surabi, for instance, is a type of food made of rice flour, which was first developed by the local in response to the high-class pancake for the elites during the Dutch colonial era. Accordingly, food innovation that is based on the identity of Bandung becomes part of that culturally defined local. Another form of local food is developed by Rahsa Nusantara, a traditional herbal drink (jamu) that is made from locally sourced spices and herbs. This is local not only in its cultural dimension, but also in its spatial dimension. The owner has aimed to use local ingredients for her jати as opposed to imported herbs that are more expensive and not environmentally friendly. For example, instead of using Indian cardamom, the owner prefers to use local cardamom that is grown by her fellow farmers.

A different form of local relates to its social dimension, whereby local food also means supporting local communities to improve their livelihood through a sustainable way of producing food. This is the case with Baduy Forest Honey, a product made by Baduy traditional community at the western most of Java. The forest honey is made from naturally grown flowers in a community forest, and processed in a sustainable way. The aim of this business is two-fold, to build awareness among the middle class in Bandung and Jakarta on the 
importance of local products, and to help Baduy community in maintaining their ecology and improving their livelihood.

\subsection{Food Distribution: Between the Conventional and the Alternatives}

To this term, we go further in understanding another cluster that is at the centre of food provisioning, but similarly inviting a lot of debates on its legitimacy. We define food outlet as a cluster of activities in which foods or food products reach consumers at the end of the supply chain. At one end of the spectrum, Pasar Sehat is the utopian vision of a local food outlet where farmers meet and exchange values directly with consumers (Mount, 2012). In other instances, local restaurants and cafes promoting organic, seasonal and local produces in their ingredients have become more significant in the past decade. Within the city, we identify at least five local outlets that take on labels like local, organic and vegan as their selling points; and they are growing in profits and customers. Yet, even with Pasar Sehat and these local outlets combined, they still account for a small fraction of the food supply, albeit grow incrementally annually.

One of the outlets, a café called Serasa, sells salad as their main line of products. Produce becomes the key of success in their business. It has become their commitment to use locally grown, organic vegetables from Bandung and the surrounding areas. This notwithstanding, they never label their café as local nor organic. For them, having consumers, especially youth, to consume healthy foods such as salads is a huge accomplishment in itself. Labelling the food as local or organic would instead scare people off their café. Another example is Salam Sehat, a restaurant that channels produces from the owner's organic farm in the outskirt of Bandung. The farm was meant as a place to grow the owner's personal food, but ended up consumed by many more people.

At another end of the spectrum, it is the traditional wet markets that in reality play the most part as a food outlet for the majority of consumers in Bandung. The extent to which wet markets are able to bear the task as local food actors entirely depends on the flexibility of these actors to adjust their goods to consumers' demands. Wet markets have that sense of communality whereby traders can bargain and interact with consumers. However, the stigma that wet markets are wet, dirty and slushy becomes a hindrance for the growth of this type of market, particularly in the presence of supermarkets and convenience store (as the name implies). A growing movement now emerges to protect and enliven the traditional market so that people will still come and conserve the old-fashioned way of buying produce.

\subsection{Urban Agriculture and Community Gardens: Connecting Food and People}

Based on a similar idea that people need to interact with each other better within a community, community gardening initiatives position themselves to be the gateway between food and people. Community garden has become a growing phenomenon worldwide (Kurtz, 2001), and it shows a unique form of community's direct involvement with food provisioning outside the market framework. There are more than five community gardens spread across various sub-urban areas within Bandung city limits, located sparsely in various public spaces or abandoned lands and established for different reasons; some for the enjoyment of gardening and some for the necessity of food provisioning.

Indeed, there are various objectives attached to different community gardens. Arcamanik community garden exemplifies one of these reasons. Established in 2013, Arcamanik community garden's main purpose is to create a space for people to nurture a sense of community through a particular activity: farming. Another example is the Maleer Community Garden that was established not only to provide a space for community participation, but also to educate people on the importance of basic life skills such as gardening. Some others like Hydroponic Learners Club, Gardening Bandung, and Indonesian Organic Community are not attached to a particular space, but formed as a network of keen gardeners and food enthusiasts to facilitate the sharing of information and seeds. For others like Cibunut and Sekepicung community development projects, gardening is a part of the bigger picture in attaining a sustainable community life - other means include youth support movement, waste management, and community education.

Community gardens and similar groups are examples of how community interacts through network outside their locality. As stated by the director of Kebun Belajar, a permaculture garden at the eastern of Bandung, people that support the garden come from different places, even outside that suburban area. In RW Berkebun (lit. Gardening Neighbourhood) program, gardens were established through collaboration between the city council and practitioners from other community gardens looking to replicate the effect of such a movement. Funds are brought from donors, charitable organizations and corporations alike. Experts from universities and practitioners share their technical knowledge with the volunteers. It is through this type of initiatives that community engages both with food and people in its deeper sense. 


\subsection{Research and Education}

As we mentioned earlier, the academic life has also contributed to the development of Bandung's local food system through at least two ways: applied research and student activism. Within the realm of applied research, contributions of academia stretch from the farm level to consumer behaviours. In ITB, one of the largest universities in Bandung, there are at least six academic faculties that connect with multiple facets of food system through various studies; among others addressing local food governance, developing technological innovation in doing smart farming, and implementing start-up business models in response to the growing food movement.

What emerges out of the campus life is also student activism. Some of them include U-Green, a student organization that seeks to promote environmental causes by campaigning to grow food in your neighbourhood and manage organic waste through various innovative ways. In a wider context, Greeneration is a youth-based organization and start-up business in Bandung, which focuses in wide-spreading zero-carbon attitude and practices in response to the emerging climate change issue. These particular students and youth-based groups raise the prominence of locality as part of the solution for larger environmental and social problems that the society is facing. Yet, it also illustrates that local carries a political load in opposition to the globalization of diets (Lang, 1999; Hinrichs, 2000).

At the production level, organizations such as Indonesian Organic Community, a national-level organic-orientated group, promotes a more sustainable farming through its exclusive website, education program and festivals. Independent projects like Gardening Bandung (that grew into Gardening Indonesia) facilitate the development and functioning of urban agriculture through volunteer-based projects. Other actors engage beyond the scope of a local food system, but occasionally cover food as a pertinent issue. At a political level, city council's programs such as Bandung Agri Market and Gardening Neighbourhood channel aspirations of other actors to the city's policy-making strategy-formulating. Seeing this, we realise that the smallest commitment to build a better community will give a significant impact on the way in which the food system is shaped. These actors have put the finishing touches to the growth and evolution of Bandung's local food system, as we will discuss in the next part of this paper.

\subsection{From Initiatives to Networks to Movements}

Local food initiatives have indeed grown rapidly in Bandung and the surrounding areas. However, these actors are far from working individually. They are also already connected with each other in considerable ways. Engagements between actors take place in various time and places, depending on which aspects of the food system they touch. For examples, Pasar Sehat facilitates interactions between local food producers, processing entities, food distribution and consumers at large on a weekly basis. This occasion provides not only market activities, but also, as we witnessed directly, a place to engage deeper with the local food in which they discuss future plans ahead. Similar things happen during a regular working bee in community gardens or permaculture gardeners' meeting where they often invite experts from the university or practitioners alike.

The documentation of local food initiatives in Bandung has lead us to believe that these initiatives are connected with each other in a form of strongly-knitted networks, and now even evolving into a collective grass-root movement. We identified this as a movement based on the argument that a movement can be built and transformed from mere, unconnected, initiatives that realise each other's potentials and seek to achieve larger impacts. We substantiate this argument by seeing empirically how instances like social media chatting group and public discussions on local food considerably attracted these various groups.

We take on the example of Komunitas 1000 Kebun (lit. 1000 Gardens Community), a hub of many different initiatives (over 300 from the latest record), with which we have been involved in many research and community outreach programs (Figure 1). All of the initiatives mentioned in the previous section are part of this hub. It started in 2014 as a group of local activists and community members that wanted to do something good to their local neighbourhood, a suburb called Arcamanik at the east part of Bandung. Some have been developing their own organic farms, and others were just keen gardeners on their small patch of land. The group decided to work with the local official to grow vegetables in public spaces around their houses. It went viral as they made themselves a WhatsApp chat group. From only fewer than 10 members, within a year the group has grown into 100 members, and now has reached over 300 members (consisting of three separated WhatsApp group due to the app's inability to contain more than 254 members in one group). Most of these members are individuals that are interested in engaging with healthy lifestyle. However, many are also local food initiatives in different forms local farmers and artisans that were looking for a market place or activists that wanted to involve their community groups in a wider interest group. Geographically speaking, whereas the group started out as being 
highly localized, it now covers members not only from Bandung (or Java Island for that matter), but also from Papua, Kei, Sumatra and Bali.

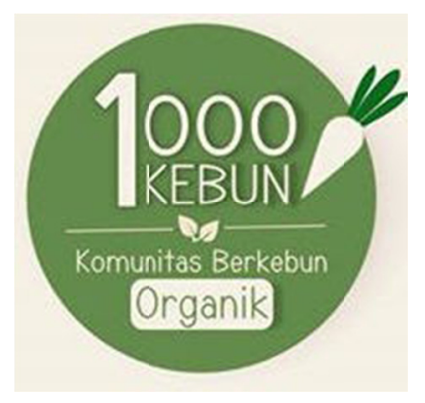

Figure 1. Komunitas 1000 Kebun Logo

Some of the members began to offer their produces to the chat group, resulting in an enthusiastic response from the members. On a routine basis, members would hear someone offering organic bananas, after which people would start to place their purchase orders. This ongoing online market pushed the board to come out with the idea of Pasar Sehat, as described in the previous section of this paper. The occasional market began to take a more structured form. A small committee from the community itself volunteered to become curators for the products sold in Pasar Sehat as well as in the online market. They created their own certification system for the products offered by members. The occasional market itself is now scheduled more routinely as a form of community business. Schools or other institutions that have large enough parking spaces or courtyard can invite the tenants to hold Pasar Sehat, both to promote the institutions and gain profit from the event. In addition, the online market has taken a more structured form as well, with a subsidiary called Warung 1000 Kebun (lit. 1000 Gardens kiosk) with a task to facilitate the online transactions in the group.

However, Komunitas 1000 Kebun is not only about business interests. It is in their mission to promote healthy and environmentally friendly life-style to a wider audience through food. Some of the activists in the network have taken bold steps in speaking on behalf of the group to promote organic lifestyle and community projects in Bandung and other areas in Indonesia. Requests to support local initiatives began to transpire. Among the projects are helping youth movement in Kei Island, a small island eastern part of Indonesia, to rejuvenate their land for farming and promote healthy food to the younger generation of Kei; building an urban farming installation for prisons, bus stations and public spaces in Bandung; educating children in schools about healthy food; being invited as gardening experts in a variety of TV shows; inspiring young students in a reputable national youth forum; to designing a community garden for the presidential palace in Jakarta. These projects involved various, willing, members of the community group, but run by a smaller organizing team that oversees the integrity of the group. This group, as an entity, also collaborates with other community hubs to create far-reaching programs that go beyond food.

The emerging prominence of Komunitas 1000 Kebun within the public interest and political decision making has, to some extent, attracted involvement of a wide spectrum of actors to the system for their own interests. This brings us to an important finding relevant to the argument in this paper; that the fuel to run the local food engine is already there. Bandung's local food system then can be seen as an ensemble of a multitude of actors seeking to pursue their objectives, but at the same time contribute to the benefits of the food system and the community in general. It has indeed become a movement in its own right.

\section{Conclusions}

The case of Bandung's local food system is both unique and ubiquitous. The uniqueness lends to the formulation of a specific prescription on building a local food system that can only be applied to the city and not elsewhere. We agree with Kevin Morgan's (2013b) argument that there is no one-size-fits-all in designing a food policy and that it all depends on the local context of the society. In Bandung, a combination of factors such as the size and demography of the population, influx and access of information, historical profiles of the communities and the geographical landscape of the region contributes to a unique case where local food is constructed through a bottom-up approach. On the other hand, the ubiquity of the case we bring forth also contributes to a wider discourse of food systems. To an extent, Bandung represents whole other cities that are struggling to build for a 
resilient and sustainable food system in the face of global crises (see also Allen et al., 2003; Friedmann, 2012). In these cities, a successful food policy is contingent on the involvement of a multitude of actors - communities, academia, practitioners, policy-makers and businesses. To conclude, we want to relate our finding with a generic type of local food development where movements started out as initiatives that connected with likeminded actors to form coherent networks. The cases of alternative agrifood initiatives in California, USA (as elaborated by Allen et al., 2003), Dunedin, New Zealand (Dwiartama \& Piatti, 2016), or Ontario, Canada (Mount, 2012) have also substantiated this conception of local food development, and this study therefore enriches the findings to also include a growing city in one of South East Asian emerging economies.

Instead of focusing on a particular phenomenon within the discourses of agri-food studies (e.g. farmers market, urban agriculture, etc.), this paper offers a first glimpse of the complex relationships and interactions occurring between those various actors under the auspice of evolving Bandung's local food system. This enables us to see that the constructive effect is caused not only by the capacity of those actors, but also by the interconnectedness and engagement taking place between the actors. By being inclusive in our mapping, we are able to observe the dynamics that shape the system. We think that the biggest challenge to achieve a sustainable local food system is managing the divergence that comes out of, and is brought by, the inclusiveness of a variety of actors and going on to move together as a single grass-root movement; and we question whether Bandung, and many other cities in Southeast Asia to be more general, is yet to face a more difficult challenge ahead with this growing movement As noted by Mount (2012), opportunities are widely opened, but also need to be critically examined, when it comes to the governance of alternative food movements.

\section{References}

Allen, P., FitzSimmons, M., Goodman, M., \& Warner, K. (2003). Shifting plates in the agrifood landscape: the tectonics of alternative agrifood initiatives in California. Journal of rural studies, 19(1), 61-75. https://doi.org/10.1016/S0743-0167(02)00047-5

Badan Pusat Statisik. (BPS) (2016). Statistik Kependudukan Jawa Barat 2016. Diakses dari Retrieved 30 September 2016, from http://www.bps.go.id/.

Carolan, M. (2012). The sociology of food and agriculture. Routledge.

DuPuis, E.M., \& Goodman, D. (2005). Should we go 'home' to eat? Toward a reflexive politics of localism. Journal of Rural Studies, 21,359-71. https://doi.org/10.1016/j.jrurstud.2005.05.011

Dwiartama, A., \& Piatti, C. (2016). Assembling local, assembling food security. Agriculture and Human Values, 33,153-164. https://doi.org/10.1007/s10460-015-9624-9

Friedmann, H. (2012). Reinhabiting our Earthly Home: Ways to Reshape an Urban Foodshed. Paper presented at the $107^{\text {th }}$ American Sociological Association 2012 Annual Meeting, August 17-20, Denver, CO.

Goodman, D., DuPuis E.M., \& Goodman M.K. (2011). Alternative Food Networks: Knowledge, Practice and Politics. Routledge.

Goodman, L. A. (1961). Snowball sampling. The Annals of Mathematical Statistics, 32(1), 148-170. https://doi.org/10.1214/aoms/1177705148

Hinrichs, C. C. (2000). Embeddedness and local food systems: notes on two types of direct agricultural market. Journal of Rural Studies, 16(3), 295-303. https://doi.org/10.1016/S0743-0167(99)00063-7

Hinrichs, C. C. (2003). The practice and politics of food system localization. Journal of Rural Studies, 19(1), 33-45. https://doi.org/10.1016/S0743-0167(02)00040-2

Kjeldsen, Chris, \& Alrøe, Hugo Fjeldsted. (2006). Localness as the new orthodoxy? Critical reflections on localisation of food systems. Paper presented at Joint Organic Congress, Odense, Denmark, May 30-31, 2006.

Kurtz, Hilda. (2001). Differentiating multiple meanings of garden and community. Urban Geography, 22(7), 656-670. https://doi.org/10.2747/0272-3638.22.7.656

Lang, Tim. (1999). The complexities of globalization: The UK as a case study of tensions within the food system and the challenge to food policy. Agriculture and Human Values, 16(2), 169-185. https://doi.org/10.1023/A:1007542605470

Milestad, R., Westberg, L., Geber, U., \& Bjõrklund, J. (2010). Enhancing Adaptive Capacity in Food Systems: Learning at Farmers' Markets in Sweden. Ecology and Society, 15 (3), 29. https://doi.org/10.5751/ES-03543-150329 
Morgan, K. (2013). Urban Food Governance. Paper presented at the Dunedin City Council Community Resilience Forum Public Lecture, Dunedin, New Zealand, April $8^{\text {th }} 2013$.

Mount, P. (2012). Growing local food: scale and local food systems governance. Agriculture and Human Values, 29(1), 107-121. https://doi.org/10.1007/s10460-011-9331-0

Piatti, C., \& Dwiartama, A. (2013). Potential and challenges of a bottom-up approach towards an urban food strategy: the case of Dunedin's local food network. Paper presented (oral) at the $20^{\text {th }}$ Australasian Agri-Food Research Network Conference, 2 - 5 December 2013, Melbourne: Australia.

Reason, P., \& Bradbury, H. (Eds.) (2008). The Sage Handbook of Action Research: Participative Inquiry and Practice. Thousand Oaks, CA: SAGE Publishing. https://doi.org/10.4135/9781848607934

Wakefield, S. E. L. (2007). Reflective Action in the Academy: Exploring Praxis in Critical Geography using a "Food Movement" Case Study. Antipode, 39: 331-354. https://doi.org/10.1111/j.1467-8330.2007.00524.x

\section{Copyrights}

Copyright for this article is retained by the author(s), with first publication rights granted to the journal.

This is an open-access article distributed under the terms and conditions of the Creative Commons Attribution license (http://creativecommons.org/licenses/by/4.0/). 